\title{
Microsatellites grant more stable flanking genes
}

\author{
Reem Joukhadar ${ }^{1}$ and Abdulqader Jighly $2^{*}$
}

\begin{abstract}
Background: Microsatellites, or simple sequence repeats (SSRs), are DNA sequences that include tandem copies of specific sequences no longer than six bases. SSRs are ubiquitous in all genomes and highly mutable.

Presentation of the hypothesis: Results from previous studies suggest that flanking regions of SSR are exhibit high stability in a wide range of organisms. We hypothesized that the SSRs ability to discard weak DNA polymerases could be responsible for this unusual stability. . When the weak polymerases are being decayed over SSRs, the flanking sequences would have higher opportunity to be replicated by more stable DNA polymerases. We present evidence of the molecular basis of our hypothesis.

Testing the hypothesis: The hypothesis could be tested by examining the activity of DNA polymerase during and after a number of PCRs. The PCR reactions should be run with the same SSR locus possessing differences in the SSR length. The hypothesis could also be tested by comparing the mutational rate of a transferred gene between two transformations. The first one has a naked T-DNA (transferred DNA), while the second one has the same T-DNA flanked with two SSRs.

Implications of the hypothesis: In any transformation experiment, flanking the T-DNA fragment with SSR sequences would result in more stably transferred genes. This process would decrease the unpredictable risks that may occur because of the mutational pressure on this foreign segment.
\end{abstract}

Keywords: Microsatellite, Polymerase Chain Reaction (PCR), Polymerase slippage, Transformation

\section{Background}

Microsatellite or simple sequence repeats (SSRs) are tandem repeated DNA sequences including tandem copies of specific sequences no longer than six bases [1]. SSRs are ubiquitously distributed almost in all eukaryotic and prokaryotic genomes [2]. Their abundance and the tandem repeated nature of SSRs make the loci highly mutable loci. Two mechanisms have been attributed to this phenomenon namely [3] unequal crossing over [4] and slipping of the DNA polymerase when it run over the SSR template strand allowing one strand to hybridize with one of the multi-complimentary tandem sequences on the other strand [5]. These mechanisms results in SSR loci being highly mutable [6]; this unique mutational ratio creates a need to align these loci in a special way [7].

There are a lot of factors that affect the mutational ratio. The longer SSRs are more variable than shorter

\footnotetext{
*Correspondence: a.jighly@cgiar.org

${ }^{2}$ International Center for Agricultural Research in the Dry Areas (ICARDA), P.O. Box 5466, Aleppo, Syria

Full list of author information is available at the end of the article
}

ones; however there is no threshold for slippage occurrence [8]. It appears that SSR mutations are dependent on motif size and nucleotide content. Besides, position in genome (coding or non-coding sequences), presence on leading or lagging strand and the distance from origin of replication also affect SSR mutations [9]. Further, fidelity of replication and repair mechanisms as well as epigenetic factors may influence repeat stability [9].

Despite the high mutation rate of SSRs, their flanking regions exhibit high stability even among different taxa; there is a negative correlation between SSR length and substitution rate in nearby flanking sequence [10,11]. SSRs are increasingly being used as genetic markers for a wide range of applications such as evolution and diversity studies, genetic mapping and forensic studies [12].

\section{Presentation of the hypothesis}

Our new hypothesis assumes that SSRs may have the power to discard weak DNA polymerases and keep the more robust ones. This selective capacity of SSRs can lead to more accurate amplification of the microsatellite flanking regions. Further, SSR slippage may occur during

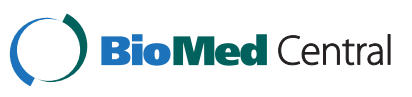

(c) 2012 Joukhadar and Jighly; licensee BioMed Central Ltd. This is an Open Access article distributed under the terms of the Creative Commons Attribution License (http://creativecommons.org/licenses/by/2.0), which permits unrestricted use, distribution, and reproduction in any medium, provided the original work is properly cited. 
the decaying and the replacment of weak polymerases. The following paragraphs would present a review on the stability of SSR flanking regions in many organisms and some supportive evidence- related to the conditions of the polymerization as well as our new molecular view of how the selection is done.

\section{The stability of SSR flanking regions}

The stability of the SSR flanking regions was investigated in different organisms; three Phytophthora species (algae) [13]; rice and bamboo [14]; cotton [15]; Brassica rapa and Arabidopsis thaliana [16]; cowpea, mung bean and adzuki bean [17]; Castanea spp. [18]; Carya [19] and wheat [20]. Similar studies have also been carried out in different animals such as fish [21]; Acropora [22]; cattle, sheep, yak, buffalo and goat [23]; Probarbus jullienii [24] and gerbils [25]; and in human genome studies where different SSR's flanking regions associated with genes expressed in the developing nervous system were compared [26]. In addition, flanking regions of EST-SSR loci demonstrated a common evolutionary origin of grass fungal endophytes taxa [27].

Recently results with pepper chloroplast genome showed that there are two sites called inverted repeat (IRa and IRb) containing high frequency of tandem repeats [28]. In this study, most of the hotspot regions in pepper chloroplast genome seem to be relayed at the middle of the biggest fragment LSC (large single copy) -about $87 \mathrm{~kb}$ - which is far from the IR sites.

These studies provide indication that SSRs may help to protect their flanking regions from different kinds of mutations.

\section{Evidences related to polymerization conditions}

Viguera et al. [29] reported that the DNA polymerase dissociates from the synthesize strand when the slippage occurs. We think that this dissociation support our assumption when SSRs replace weak DNA polymerases.

It has been reported that SSRs found on the lagging strand shows higher instability than those on the leading strand without any explanation [30]. This lends credence to our assumption because of the presence of Okazaki fragments when lagging strand is being replicated. Replicating those fragments would allow more DNA polymerases to act on them leading to a higher opportunity for weaker DNA polymerases to replicate on the lagging strand.

Further, a significant increase in DNA polymerase slippage rates was reported as a result of inefficient concentrations of ions (particularly $\mathrm{Mg}$ ions) during DNA replication [29,31]. It has been reported that magnesium-induced the assembly of a complete DNA polymerase catalytic complex [32].

Kumar et al. [33] reported that the misbalancing of dNTPs increases the mutagenesis ratio. Consistent with our hypothesis, we suggest that the long motifs with one or two types of nucleotides could cause more decayed DNA polymerases because they may create a local misbalancing of dNTPs by using limited types of nucleotides which may enhance mutation occurrences.

\section{Molecular view}

Figure 1 illustrates a ribbon diagram of one of the DNA polymerases (PDB code - 1BPX) [34]. As observed, both the template (blue) and the synthetic strands (yellow) are joined with bracket-like proteomic subunit colored with red and pink. This subunit forms a pipe that fit the 3D structure of the double stranded DNA $[35,36]$. The structure of this subunit prevents the DNA from formation of possible secondary structures (like the loop that occurs when the DNA polymerase slips) [36,37]. While this subunit is stable, the whole protein would be stable and the synthetic strand would have less errors. After building a huge number of bases, the instability of the DNA polymerase would increase as well as the errors rate [38]. Therefore, when the weak polymerase gets over an SSR locus, it would create a suitable environment to generate such loop because of the multi-complementary sequences. In vivo, the DNA polymerase would stop releasing double stranded DNA [29]. Further, the helicase enzyme would still be pushing unwinded strand toward the DNA polymerase [39-41]. This would bring heavy pressure on the weak polymerase. We assumed that when polymerase slips, its domains would separate and the free end would

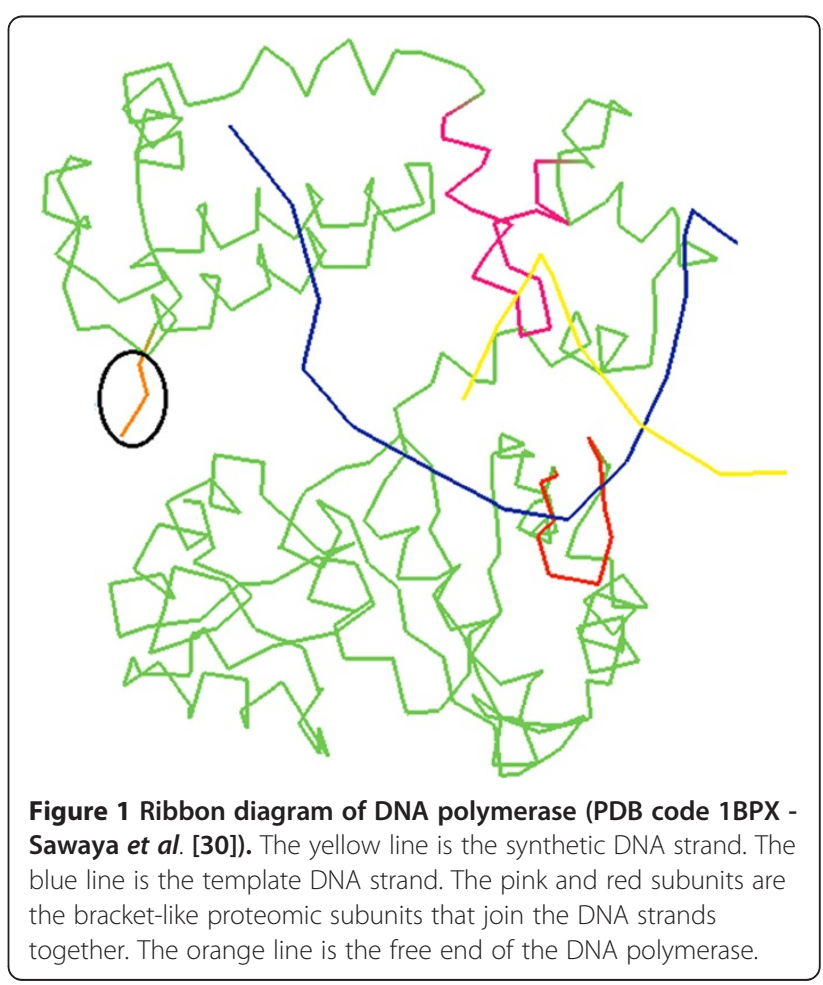




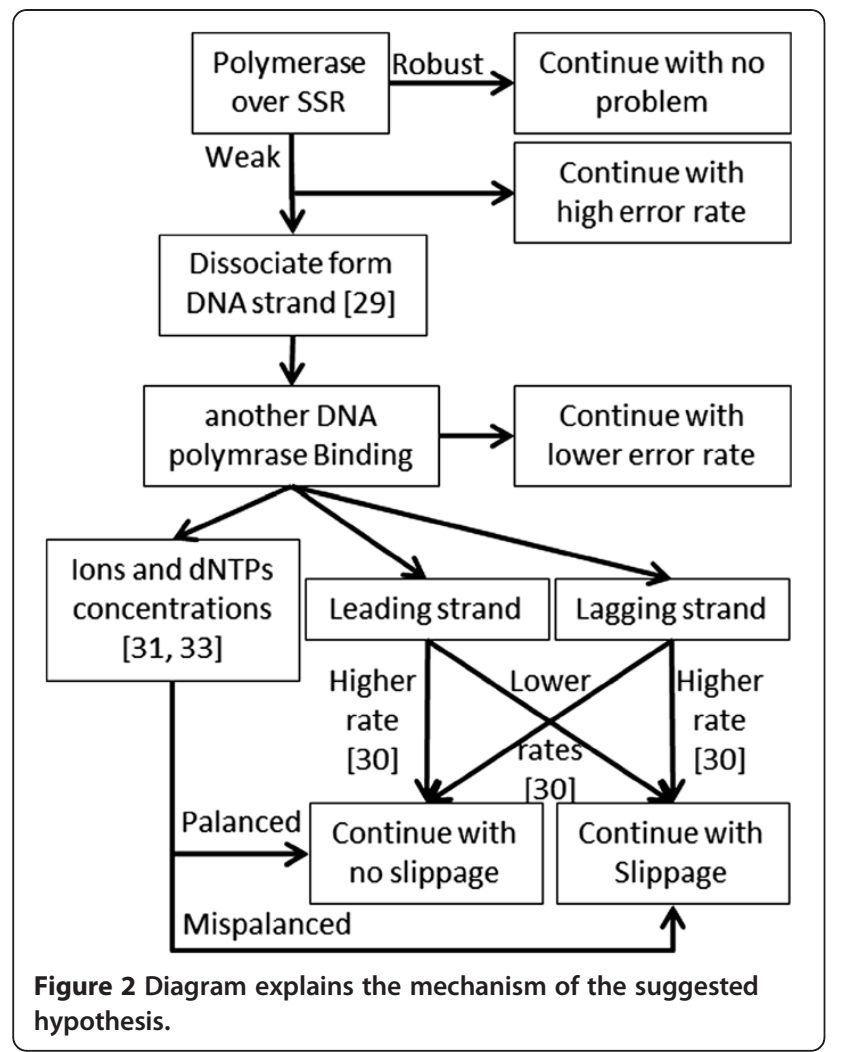

split from the other domain causing a decayed protein and the polymerase would lose its polymerization activity. It's also observed that this slippage happens in vitro during PCR reaction [5,31] and it has previously been reported that repeats undergo deletion if replication temperature is high [42]. Figure 2 demonstrates a diagram describing the whole process.

\section{Testing the hypothesis and implications of the hypothesis}

When trying to improve genetic modified organisms, it would be helpful to add an SSR region to the T-DNA. Flanking the transferred gene with SSRs on both sides would decrease the unpredictable risks that may occur if the foreign T-DNA fragment mutates. Microsatellites have been used in the T-DNA as a molecular marker in order to select the transgenic cucumber lines [43]. Microsatellites of T-DNA showed high differences in their stability. For instance, the CAG repeat of the Huntington disease exposes high stability in transgenic mice [44]. Another study showed an instable transferred microsatellite [45]. However, none of these studies or other publications that used transgenic organisms focused their studies on the stability of microsatellite flanking regions.

Our assumption could be tested by comparing the mutation rate of a transferred gene between two cases - the control and testing cases. The first is the control case, which has the T-DNA, while the second, the testing case, has the same T-DNA flanked by two SSRs. If there were significant differences between both cases, the hypothesis might be applicable. The hypothesis could also be tested by checking the DNA polymerase activities during and after many PCRs. All reactions should be carried out for the same SSR locus with differences in the SSR length and another reaction should be done without the SSR itself.

\section{Competing interests}

The authors declare that they have no competing interests.

\section{Authors' contributions}

AJ and RJ discussed the hypothesis, drafted and approved the final manuscript.

\section{Acknowledgment}

The authors would like to thank Dr. Francis C. Ogbonnaya for his valuable comments and for reviewing the final draft.

\section{Author details}

${ }^{1}$ University of Aleppo, Aleppo, Syria. ${ }^{2}$ International Center for Agricultural Research in the Dry Areas (ICARDA), P.O. Box 5466, Aleppo, Syria.

Received: 2 April 2012 Accepted: 2 October 2012

Published: 5 October 2012

\section{References}

1. Tautz D: Hypervariability of simple sequences as a general source for polymorphic DNA markers. Nucl Acids Res 1989, 17:6563-6571.

2. Merkel A, Gemmell N: Detecting short tandem repeats from genome data: opening the software black box. Brief Bioinform 2008, 9(5):355-366.

3. Chistiakov DA, Hellemans B, Haley CS, Law AS, Tsigenopoulos CS, Kotoulas G, Bertotto D, Libertini A, Volckaert FA: A microsatellite linkage map of the European sea bass Dicentrarchus labrax L. Genetics 2006, 170:1821-1826.

4. Kelkar YD, Tyekucheva S, Chiaromonte F, Makova KDL: The genome-wide determinants of human and chimpanzee microsatellite evolution. Genome Res 2008, 18(1):30-38.

5. Ellegren $\mathrm{H}$ : Microsatellites: Simple sequences with complex evolution. Nat Rev Genet 2004, 5:435-445.

6. Gow C, Noble JL, Rollinson D, Jones C: A High incidence of clustered microsatellite mutations revealed by parent-offpring analysis in an African freshwater snail, Bulinus forskalii (Gastropoda, Pulmonata). Genetica 2005, 124:77-83.

7. Jighly A, Hamwieh A, Ogbonnaya FC: Optimization of sequence alignment for SSR (Simple Sequence Repeat) regions. BMC Res Notes 2011, 4:239.

8. Leclercq S, Rivals E, Jarne P: DNA slippage occurs at Microsatellite loci without minimal threshold length in Humans: a comparative genomic approach. Genome Biol Evol 2010, 2:325-335.

9. Choudhary OP, Trivedi S: Microsatellite or simple sequence repeat (SSR) instability depends on repeat characteristics during replication and repair. J Cell and Molecular Biol 2010, 8(2):21-34.

10. Santibanez-Koref MF, Gangeswaran R, Hancock JM: A relationship between lengths of Microsatellites and nearby substitution rates in Mammalian Genomes. Mol Biol Evol 2001, 18(11):2119-2123.

11. Sekar M, Suresh E, Kumar NS, Mayak SK, Balakrishna C: Microsatellite DNA markers, a fisheries perspective. Aquaculture Asia Magazine 2009, 14(2):27-29.

12. Schlotterer $C$ : The evolution of molecular markers just a matter of fashion. Nat Rev Genet 2004, 5:63-69.

13. Schena L, Cardle L, Elcooke D: Use of genome sequence data in the design and testing of SSR markers for Phytophthora species. BMC Genomics 2008, 9:620.

14. Chen S, Lin Y, Lin C, Chen W, Yang CH, Ku H: Transferability of rice SSR markers to bamboo. Euphytica 2010, 175:23-33. 
15. Altaf-Khan M, Qureshi SN, Saha S, Jenkins JN, Brubaker CL, Reddy OU: Usefulness of SSR Derived from Tetraploid Gossypium spp. for Analyses of Diploid Gossypium spp. J Crop Improvement 2006, 16:1-20.

16. Suwabe K, Tsukazaki H, Iketani H, Hatakeyama K, Kondo M, Fujimura M, Nunome T, Fukuoka H, Hirai M, Matsumoto S: Simple sequence repeatbased comparative genomics between Brassica rapa and Arabidopsis thaliana The genetic origin of Clubroot resistance. Genetics 2006, 173:309-319.

17. Vir R, Bhat KV, Lakhanpaul S: Transferability of sequence tagged microsatellite sites (STMS) primers to pulse yielding taxa belonging to Phaseolae. IJIB 2009, 5:62-66.

18. Akkak A, Boccacci P, Marinoni DT: Cross-Species Amplification of Microsatellite Markers in Castanea spp And Other Related Species. Acta Hort. (ISHS) 2010, 866:195-201.

19. Herrera AM, Grauke LJ, Klein P: Validation Of 14 Nuclear SSR Markers Among Different Species Of The Genus Carya. Plant \& Animal Genomes XIX Conference, Town \& Country Convention Center 2011, P153.

20. Zhang L, Sun G, Yan Z, Chen Q, Yuan Z, Lan X, Zheng Y, Liu D: Comparison of Newly Synthetic Hexaploid Wheat with Its Donors on SSR Products. J Genet Genomics 2007, 34(10):939-946.

21. Zardoya R, Vollmer DM, Craddock C, Streelman JT, Karl S, Meyer A Evolutionary conservation of microsatellite flanking regions and their use in resolving the phylogeny of cichlid fished (Pisces:Perciformes). Proc R Soc Lond B 1996, 263:1589-1598.

22. Tang P, Wei NV, Chen C, Wallace CC, Allen C: Comparative Study of Genetic Variability of AAT and CTGT Microsatellites in Staghorn Coral, Acropora (Scleractinia Acroporidae). Zoological Studies 2010, 49(5):657-668.

23. Shakyawar SK, Joshi BK, Kumar D: SSR repeat dynamics in mitochondrial genomes of five domestic animal species. Bioinformation 2009, 4(4):158-163.

24. Ghiasi N, Rashid ZA, Hooshmand S, Yusoff K, Tan SG, Bhassu S: The use of locus specific microsatellite markers for detecting genetic variation in hatchery bred Probarbus jullienii. Biotechnology 2009, 8:166-170.

25. Du X, Chen Z, Li W, Tan Y, Lu J, Zhu X, Zhao T, Dong G, Zeng L: Development of Novel Microsatellite DNA Markers by CrossAmplification and Analysis of Genetic Variation in Gerbils. J Hered 2010, 101(6):710-716.

26. Riley DE, Krieger JN: Embryonic nervous system genes predominate in searches for dinucleotide simple sequence repeats flanked by conserved sequences. Gene 2009, 429:74-79.

27. De Jong E, Guthridge KM, Spangenberg GC, Forster GW: Sequence Analysis of SSR-Flanking Regions Identifies Genome Affinities between Pasture Grass Fungal Endophyte Taxa. Int J Evol Biol 2011, 10:1-11.

28. Jo YD, Park J, Kim J, Song W, Hur C, Lee Y, Kang B: Complete sequencing and comparative analyses of the pepper (Capsicum annuum L.) plastome revealed high frequency of tandem repeats and large insertiondeletions on pepper plastome. Plant Cell Rep 2011, 30:217-229.

29. Viguera E, Canceill D, Ehrlich SD: Replication slippage involves DNA polymerase pausing and dissociation. J Mol Biol 2001, 20(10):2587-2595.

30. Wang G, Vasquez KM: Models for chromosomal replication-independent non-B DNA structure-induced genetic instability. Mol Carcinog 2009, 48(4):286-298

31. Viguera E, Canceill D, Ehrlich SD: In vitro Replication Slippage by DNA Polymerases from Thermophilic Organisms. J Mol Biol 2001, 312(2):323-333.

32. Batra VK, Beard WA, Shock DD, Krahn JM, Pedersen LC, Wilson SH: Magnesium-induced assembly of catalytic complex. Structure 2006 , 14:757-766.

33. Kumar D, Abdulovic AL, Viberg J, Nilsson AK, Kunkel TA, Chabes A: Mechanisms of mutagenesis in vivo due to imbalanced dNTP pools. Nucl Acids Res 2010, 39:1-12.

34. Sawaya MR, Prasad R, Wilson SH, Kraut J, Pelletier H: Crystal structures of human DNA polymerase beta complexed with gapped and nicked DNA: evidence for an induced fit mechanism. Biochemistry 1997, 36:11205-11215.

35. Ollis DL, Brick P, Hamlin R, Xuong NG, Steitz TA: Structure of large fragment of Escherichia coli DNA polymerase I complexed with dTMP. Nature 1985, 313:762-766.

36. Steitz TA: A mechanism for all polymerases. Nature 1998, 391:231-232

37. Hubscher U, Spadari S, Villani G, Giovanni M: DNA Polymerases, Discovery Ltd: Characterization and Functions in Cellular DNA Transactions. World Scientific Publishing Co. Pte; 2010

38. Nyrén P: Enzymatic method for continuous monitoring of DNA polymerase activity. Anal Biochem 1987, 167(2):235-238.
39. Lopes M, Foiani M, Sogo JM: Multiple mechanisms control chromosome integrity after replication fork uncoupling and restart at irreparable UV lesions. Mol Cell 2006, 21:15-27.

40. Takahashi TS, Wigley DB, Walter JC: Pumps, paradoxes and ploughshares: mechanism of the MCM2-7 DNA helicase. Trends Biochem Sci 2005, 30:437-444.

41. Bochman ML, Schwacha A: The Mcm2-7 complex has in vitro helicase activity. Mol Cell 2008, 31:287-293.

42. Sarkar PS, Chang HC, Boudi FB, Reddy S: CTG repeats show bimodal amplification in E. coli. Cell 1998, 95(4):531-540.

43. Zhao L, Liao F, Wang CY, Miao C, Min WA, Li DS, Cheng MAB, Yu HX, Qiang WZ, Ju WR, Gang LM: Generation of transgenic cucumbers with expression of a ten-tandem repeat long acting GLP-1 analogue and their biological function on diabetic rats. Chinese Sci Bull 2009, 54:4658-4663.

44. Goldberg YP, Kalchman MA, Metzler M, Nasir J, Zeisler J, Graham R, Koide HB, Kusky JO, Sharp AH, Ross CA, Jirik F, Hayden MR: Absence of disease phenotype and intergenerational stability of the CAG repeat in transgenic mice expressing the human Huntington disease transcript. Hum Mol Genet 1996, 5(2):177-185.

45. Adachi H, Kume A, Li M, Nakagomi Y, Niwa H, Do J, Sang C, Kobayashi Y, Doyu M, Sobue G: Transgenic mice with an expanded CAG repeat controlled by the human AR promoter show polyglutamine nuclear inclusions and neuronal dysfunction without neuronal cell death. Hum Mol Genet 2001, 10(10):1039-1048.

doi:10.1186/1756-0500-5-55

Cite this article as: Joukhadar and Jighly: Microsatellites grant more stable flanking genes. BMC Research Notes 2012 5:556.

\section{Submit your next manuscript to BioMed Central and take full advantage of:}

- Convenient online submission

- Thorough peer review

- No space constraints or color figure charges

- Immediate publication on acceptance

- Inclusion in PubMed, CAS, Scopus and Google Scholar

- Research which is freely available for redistribution 